\title{
Ion fluxes in silver catfish (Rhamdia quelen) juveniles exposed to different dissolved oxygen levels
}

\author{
Felipe Link de Rosso, Keidi C. S. Bolner and Bernardo Baldisserotto
}

Low dissolved oxygen levels in the water (hypoxia) can be provoked by oxygen consumption by fish and other organisms, organic matter decomposition, phytoplankton blooms, and temperature increase. The objective of the present study was to investigate $\mathrm{Na}^{+}, \mathrm{Cl}^{-}, \mathrm{K}^{+}$, and ammonia fluxes in silver catfish (Rhamdia quelen) exposed to different dissolved oxygen levels. Juveniles $(9 \pm 1 \mathrm{~g})$ maintained at $6.0 \mathrm{mg} . \mathrm{L}^{-1}$ dissolved oxygen were transferred to four $40 \mathrm{~L}$ aquaria with different dissolved oxygen levels (in mg.L $\mathrm{L}^{-1}$ ): 6.0, 4.5, 3.5, and 2.5. In another series of experiments, juveniles were acclimated at 6.0 or $2.5 \mathrm{mg} . \mathrm{L}^{-1}$ dissolved oxygen levels, and then placed in two $40 \mathrm{~L}$ aquaria with $6.0 \mathrm{mg} . \mathrm{L}^{-1}$ dissolved oxygen. For both series of experiments, $1,24,48$ or $120 \mathrm{~h}$ after transference juveniles were placed in individual chambers of $200 \mathrm{~mL}$ (with the same dissolved oxygen levels of their respective aquaria) for $3 \mathrm{~h}$. Water samples were collected for analysis of $\mathrm{Na}^{+}, \mathrm{Cl}^{-}, \mathrm{K}^{+}$, and ammonia levels. The obtained results allow concluding that exposure to $2.5 \mathrm{mg} \cdot \mathrm{L}^{-1}$ dissolved oxygen levels promotes loss of ions and lower ammonia excretion in silver catfish juveniles, but these losses are rapidly stabilized for $\mathrm{Na}^{+}$and $\mathrm{Cl}$. Exposure to less hypoxic levels also changes ion fluxes and ammonia excretion, but there is no clear relationship between both parameters in this species. Therefore, silver catfish osmoregulation seems to be affected when this species is transferred from normoxic to hypoxic waters and vice-versa.

Baixos níveis de oxigênio dissolvido na água (hipóxia) podem ser causados pelo consumo de oxygênio por peixes e outros organismos, decomposição de matéria orgânica, "blooms" de fitoplâncton e aumento de temperatura. O objetivo do presente estudo foi analisar os fluxos de $\mathrm{Na}^{+}, \mathrm{Cl}^{-}, \mathrm{K}^{+}$e amônia em jundiás (Rhamdia quelen) expostos a diferentes níveis de oxigênio dissolvido. Juvenis $(9 \pm 1 \mathrm{~g})$ mantidos em $6,0 \mathrm{mg} . \mathrm{L}^{-1}$ oxigênio dissolvido foram transferidos para quatro aquários de $40 \mathrm{~L} \mathrm{com}$ diferentes níveis de oxigênio dissolvido (em mg. $\mathrm{L}^{-1}$ ): 6, $0 ; 4,5 ; 3,5$ e 2,5. Em outra série de experimentos, juvenis foram aclimatados a 6,0 ou $2,5 \mathrm{mg} \cdot \mathrm{L}^{-1}$ oxigênio dissolvido e então colocados em dois aquários de $40 \mathrm{~L}$ com $6,0 \mathrm{mg} . \mathrm{L}^{-1}$ oxigênio dissolvido. Para ambas séries de experimentos, 1, 24, 48 ou $120 \mathrm{~h}$ depois da transferência os juvenis foram colocados em câmaras individuais de $200 \mathrm{~mL}$ (com os mesmos níveis de oxigênio dissolvido dos seus respectivos aquários) por $3 \mathrm{~h}$. Amostras de água foram coletadas para análise dos níveis de $\mathrm{Na}^{+}, \mathrm{Cl}^{-}, \mathrm{K}^{+}$e amônia. Os resultados obtidos permitem concluir que a exposição a 2,5 mg.L${ }^{1}$ oxigênio dissolvido promove uma perda de íons nos juvenis de jundiá, mas estas perdas são estabilizadas rapidamente no caso de $\mathrm{Na}^{+} \mathrm{e} \mathrm{Cl}$. A exposição a níveis não tão hipóxicos também altera os fluxos iônicos, mas não há nenhuma relação clara entre ambos parâmetros. Portanto, a osmorregulação do jundiá parece ser afetada quando exemplares são transferidos de águas normóxicas to hipóxicas e vice-versa.

Key words: Oxygen saturation, Osmoregulation, Jundiá.

\section{Introduction}

Low dissolved oxygen levels in the water (hypoxia) can be provoked by oxygen consumption by fish and other organisms, organic matter decomposition, phytoplankton blooms, and temperature increase (Rantin \& Marins, 1984). Fish compensate oxygen shortage by increasing ventilatory tidal volume and/or ventilation rate, which led to hyperventilation and consequently an increase in gill ventilation
(Sakuragui et al., 2003; Evans et al., 2005; Xu et al., 2006). This increase in gill ventilation is also accompanied by haemodynamic alterations to increase blood flow in the gills to enhance gas exchange (Sundin, 1999). Freshwater fish are hyperosmotic in relation to the environment and present an influx of water and loss of ions by diffusion in the gills (Baldisserotto, 2003). Therefore, the increase in gill blood flow and perfusion pressure caused by hypoxia could lead to higher ion loss because it would stimulate diffusive efflux. As hy-

Departamento de Fisiologia e Farmacologia, Universidade Federal de Santa Maria, 97105.900 Santa Maria, RS, Brazil. e-mail: bernardo@smail.ufsm.br 
poxic conditions also change the activity of several transporters $\left(\mathrm{Na}^{+} / \mathrm{H}^{+}, \mathrm{K}^{+} / \mathrm{Cl}^{-}\right)$and $\mathrm{Cl}^{-}$channels in erythrocytes of various fishes, and inhibit $\mathrm{Na}^{+} / \mathrm{K}^{+}$pump in rainbow trout hepatocytes (Nikinmaa, 2002), whole body ion influx could also be affected.

There are no studies of effect of hypoxia on osmoregulation in teleosts, but at least for rainbow trout (Oncorhynchus mykiss) there is a clear increase in $\mathrm{Na}^{+}$diffusive efflux whenever oxygen uptake rate (and consequently, blood flow in the gills) increases due to exercise (Gonzalez \& McDonald, 1992). Exhaustive exercise also increased ion loss in species of a broad spectrum of habitats, as common shiner (Notropis cornutus), lake trout (Salvelinus namaycush), rainbow trout, killifish (Fundulus heteroclitus), smallmouth bass (Micropterus dolomieu), banded sunfish (Enneacanthus obesus), and others because there is an increase of gill water flow and intralamellar blood pressure in this situation (Gonzalez \& McDonald, 1994).

Studies of ion fluxes in fish were performed with specimens exposed to optimal dissolved oxygen levels. As freshwater fishes can frequently be exposed to hypoxic environments, the objective of this study was to analyze ion fluxes in silver catfish juveniles (Rhamdia quelen) exposed to different dissolved oxygen levels.

\section{Material and Methods}

Silver catfish juveniles $(9 \pm 1 \mathrm{~g})$ were purchased from Bela Vista fish culture (São João do Polêsine, RS). Fish were transported to the Laboratory of Fish Physiology of the Universidade Federal de Santa Maria and were kept for at least two weeks in a continuously aerated $\left(6.0 \mathrm{mg} . \mathrm{L}^{-1}\right.$ dissolved oxygen) $250 \mathrm{~L}$ tank (minimum $20 \%$ water renewal per day) and fed commercial feed juveniles Supra with $42 \%$ protein (Alisul Alimentos S.A., Carazinho, Brazil) to satiety once a day. After this acclimation period 160 juveniles were separated into four $40 \mathrm{~L}$ aquaria with different dissolved oxygen levels (in mg. $\mathrm{L}^{-1}$ ): $6.0 \pm 0.2,4.5 \pm 0.2,3.5 \pm 0.1$, and $2.5 \pm 0.2$ (or $75.7 \pm 2.5,56.8 \pm 2.5,44.1 \pm 1.3$, and $31.5 \pm 2.5 \%$ oxygen saturation, respectively). In another series of experiments, to verify the effect of transference of hypoxia-adapted fish to normoxia on ion fluxes, silver catfish juveniles were maintained for 3 weeks in $250 \mathrm{~L}$ tanks with 6.0 or $2.5 \mathrm{mg} . \mathrm{L}^{-1}$ dissolved oxygen levels. After this period juveniles were placed in two $40 \mathrm{~L}$ aquaria with $6.0 \mathrm{mg} . \mathrm{L}^{-1}$ dissolved oxygen.

For both series of experiments, 1, 24, 48 or $120 \mathrm{~h}$ after transference to the $40 \mathrm{~L}$ aquaria, juveniles (different groups of 10 juveniles were used for each time) were placed in individual chambers of $200 \mathrm{~mL}$ with the same dissolved oxygen levels of their respective aquaria. After a 10 min settling period, water samples $(5 \mathrm{~mL})$ were taken then and $3 \mathrm{~h}$ later for determination of $\mathrm{Na}^{+}, \mathrm{K}+, \mathrm{Cl}^{-}$, and ammonia concentrations. Previous experiments demonstrated that net ion fluxes of juveniles maintained for $24 \mathrm{~h}$ in chambers with $6.0 \mathrm{mg}$. $\mathrm{L}^{-1}$ dissolved oxygen levels were not significantly different from the fluxes of those which measurements started around $10 \mathrm{~min}$ after placing them in the chambers. Dissolved oxygen levels of the chambers were measured every $30 \mathrm{~min}$. The dissolved oxygen levels in the aquaria and chambers were maintained bubbling air (for oxygenation) or nitrogen (for deoxygenation). Room temperature $\left(22^{\circ} \mathrm{C}\right)$ was maintained with an air conditioner.

Waterborne $\mathrm{Na}^{+}$and $\mathrm{K}^{+}$levels were measured with a B262 flame photometer (Micronal), and $\mathrm{Cl}^{-}$levels by the colorimetric assay as described by Zall et al. (1956). Ammonia levels were determined according to Verdouw et al. (1978). Net ion and ammonia fluxes were calculated from the changes in the ion or ammonia concentration of the bathwater over the $3 \mathrm{~h}$ period according to the equation proposed by Gonzalez et al. (1998):

$$
\text { Jnet }=\mathrm{V}\left([\mathrm{ion}]_{1}-[\mathrm{ion}]_{2}\right) .(\mathrm{Mt})^{-1} \text {, }
$$

where [ion $]_{1}$ and $[i o n]_{2}$ are the bath ion concentrations at the beginning and end of the flux period, respectively, $\mathrm{V}$ is the bath volume in liters, $\mathrm{M}$ is the mass of the fish in $\mathrm{kg}$, and $t$ is the duration of the flux period in hours.

Dissolved oxygen levels of the tanks, aquaria and chambers were measured with oxymeter YSI (model Y 5512), $\mathrm{pH}$ levels (7.8 - 8.2) with pH meter DMPH-2 (Digimed, São Paulo, Brazil), and water hardness $\left(38 \pm 1.5 \mathrm{mg} \mathrm{L}^{-1} \mathrm{CaCO}_{3}\right)$ was analyzed by the EDTA titrimetric method, alkalinity $(40.2 \pm 0.3 \mathrm{mg}$ $\mathrm{L}^{-1} \mathrm{CaCO}_{3}$ ) and nitrite (maximum $0.01 \mathrm{mg} \mathrm{L}^{-1}$ ) according to Boyd and Tucker (1992) at the beginning and the end of the experiment. Waterborne $\mathrm{Na}^{+}, \mathrm{K}^{+}$and $\mathrm{Cl}^{-}$levels in the aquaria were (in mmol/L): $0.3 \pm 0.05,0.07 \pm 0.01$ and $0.05 \pm 0.01$, respectively.

Homogeneity of variances among the groups was verified with Levene test. Data of $\mathrm{Na}^{+}, \mathrm{Cl}^{-}$and ammonia fluxes presented homogeneous variances, so comparisons among different treatments and times were made by two-way Anova, followed by Tukey test. Data of $\mathrm{K}^{+}$fluxes were not homocedastic, and consequently comparisons among different treatments were made by Kruskall-Wallis Anova and Mann-Whitney test. All tests were made with the software Statistica. Minimum significance level was $\mathrm{P}<0.05$.

\section{Results}

Silver catfish juveniles maintained at $6.0 \mathrm{mg} \cdot \mathrm{L}^{-1}$ dissolved oxygen and transferred to chambers with the same level of dissolved oxygen showed low $\mathrm{Na}^{+}$efflux, which kept constant up to $120 \mathrm{~h}$ of experiment. The transference of juveniles adapted to $6.0 \mathrm{mg} . \mathrm{L}^{-1}$ dissolved oxygen to aquaria with $3.5 \mathrm{or}$ $4.5 \mathrm{mg} . \mathrm{L}^{-1}$ dissolved oxygen also did not change net $\mathrm{Na}^{+}$fluxes in the first $24 \mathrm{~h}$. However, $\mathrm{Na}^{+}$influxes significantly different from the efflux of those maintained at $6.0 \mathrm{mg} . \mathrm{L}^{-1}$ dissolved oxygen were observed 48 and $120 \mathrm{~h}$ after transference of the juveniles to these lower dissolved oxygen levels. Juveniles transferred to $2.5 \mathrm{mg} . \mathrm{L}^{-1}$ dissolved oxygen presented a significantly higher $\mathrm{Na}^{+}$efflux in the first hour and at 24 and $48 \mathrm{~h}$ after transference lower $\mathrm{Na}^{+}$efflux than those kept at $6.0 \mathrm{mg} . \mathrm{L}^{-1}$ dissolved oxygen (Fig. 1A). 

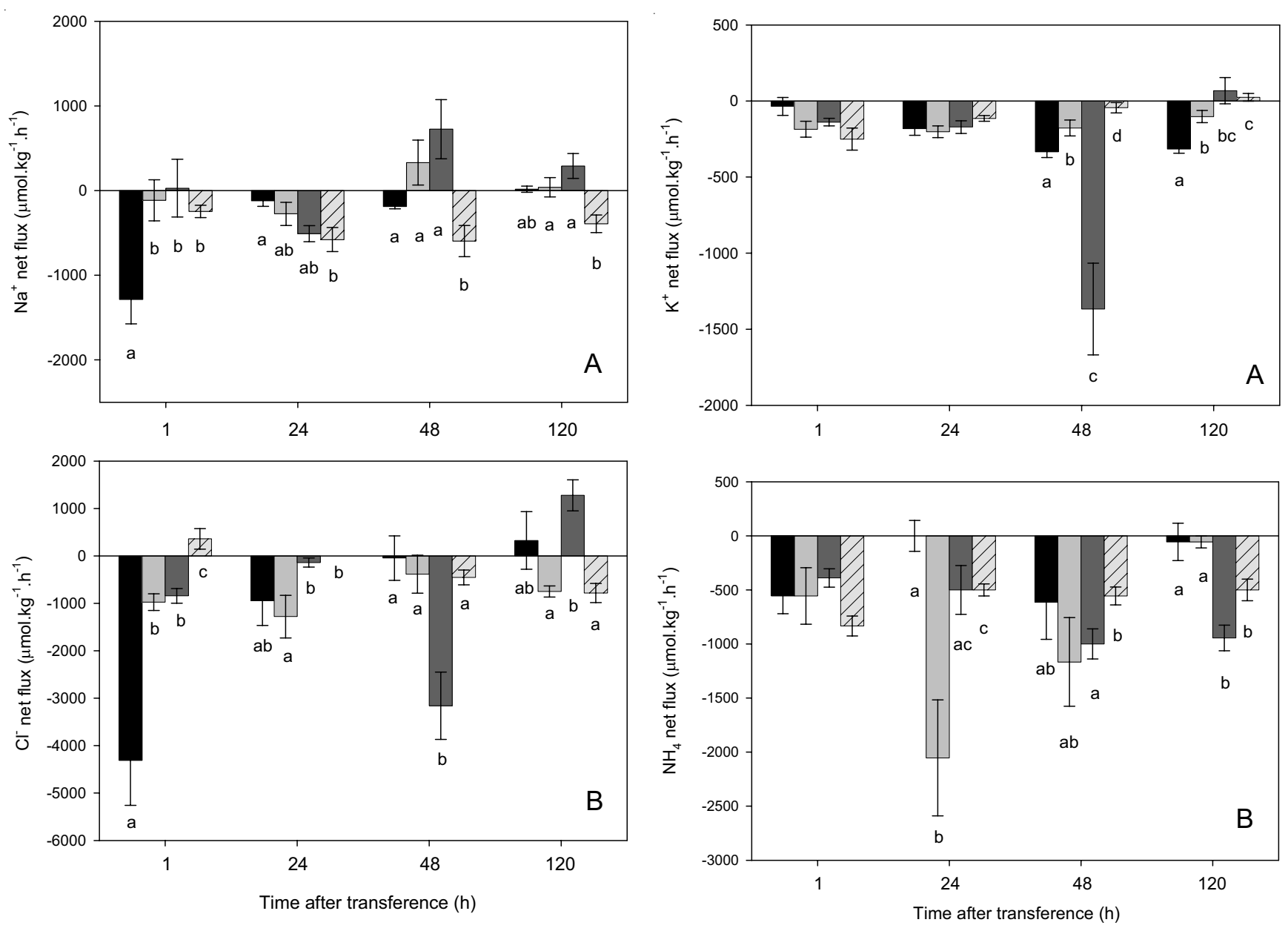

Dissolved oxygen levels (mg. $\left.\mathrm{L}^{-1}\right)$

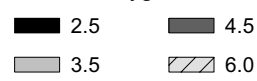

Dissolved oxygen levels (mg. $\left.\mathrm{L}^{-1}\right)$

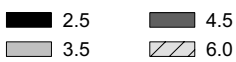

Fig. 1. $\mathrm{Na}^{+}(\mathrm{A})$ and $\mathrm{Cl}^{-}(\mathrm{B})$ net fluxes of silver catfish juveniles acclimated at $6.0 \mathrm{mg} . \mathrm{L}^{-1}$ dissolved oxygen levels and transferred to aquaria with different oxygen dissolved levels. Data expressed as mean \pm SEM. Positive values indicate net influxes, and negative values net effluxes. Different letters under the bars indicate significant difference among treatments at the same time after transference by two-way ANOVA and Tukey test $(\mathrm{P}<0.05)$.

There was a $\mathrm{Cl}^{-}$influx in the first hour, followed by low effluxes (but no significant differences among them) in silver catfish juveniles maintained at $6.0 \mathrm{mg} . \mathrm{L}^{-1}$ dissolved oxygen and transferred to chambers with the same level of dissolved oxygen. Transference to lower dissolved oxygen levels led to significantly higher $\mathrm{Cl}^{-}$effluxes in the first hour, but after $24 \mathrm{~h}$ only those exposed to $3.5 \mathrm{mg} . \mathrm{L}^{-1}$ dissolved oxygen still showed higher $\mathrm{Cl}^{-}$efflux than those maintained at $6.0 \mathrm{mg} . \mathrm{L}^{-1}$ dissolved oxygen. Forty-eight and 120 hours after transference fish exposed to $4.5 \mathrm{mg} . \mathrm{L}^{-1}$ dissolved oxygen showed higher $\mathrm{Cl}^{-}$efflux and influx, respectively, than juveniles kept at $6.0 \mathrm{mg} . \mathrm{L}^{-1}$ dissolved oxygen (Fig. 1B).

Juveniles maintained at $6.0 \mathrm{mg} . \mathrm{L}^{-1}$ dissolved oxygen presented low $\mathrm{K}^{+}$effluxes in all times and no significant differences

Fig. 2. $\mathrm{K}^{+}(\mathrm{A})$ and $\mathrm{NH}_{4}^{+}$(B) net fluxes of silver catfish juveniles acclimated at $6.0 \mathrm{mg} . \mathrm{L}^{-1}$ dissolved oxygen levels and transferred to aquaria with different oxygen dissolved levels. Data expressed as mean \pm SEM. Positive values indicate net influxes, and negative values net effluxes. Different letters under the bars indicate significant difference among treatments at the same time after transference by one-way ANOVA and Tukey test $\left(\mathrm{NH}_{4}^{+}\right)$or by Kruskall-Wallis Anova and Mann-Whitney test $\left(\mathrm{K}^{+}\right)(\mathrm{P}<0.05)$.

among them. Significantly higher $\mathrm{K}^{+}$effluxes were observed $48 \mathrm{~h}$ after transference to $2.5,3.5$ and $4.5 \mathrm{mg} . \mathrm{L}^{-1}$ dissolved oxygen levels, but after $120 \mathrm{~h}$ those transferred to $4.5 \mathrm{mg} . \mathrm{L}^{-1}$ showed a decreased of these effluxes down to the same values of those maintained at $6.0 \mathrm{mg} . \mathrm{L}^{-1}$ dissolved oxygen (Fig. $2 \mathrm{~A}$ ).

There was no significant difference on ammonia fluxes among treatments $1 \mathrm{~h}$ after transference. However, $24 \mathrm{~h}$ later juveniles transferred to $2.5 \mathrm{mg} . \mathrm{L}^{-1}$ dissolved oxygen showed significantly lower ammonia flux than those transferred to 6.0 and $3.5 \mathrm{mg} . \mathrm{L}^{-1}$ dissolved oxygen. In addition, those transferred to $3.5 \mathrm{mg} . \mathrm{L}^{-1}$ dissolved oxygen presented the significantly highest ammonia flux. Forty eight hours after transfer- 
ence juveniles transferred to $4.5 \mathrm{mg} . \mathrm{L}^{-1}$ dissolved oxygen showed significantly higher ammonia fluxes than those transferred to $6.0 \mathrm{mg} . \mathrm{L}^{-1}$ dissolved oxygen. After $120 \mathrm{~h}$ ammonia fluxes were significantly lower in juveniles transferred to 2.5 and $3.5 \mathrm{mg} . \mathrm{L}^{-1}$ dissolved oxygen levels than in those transferred to higher dissolved oxygen levels (Fig. 2B).

In the second series of experiment, juveniles acclimated to $2.5 \mathrm{mg} . \mathrm{L}^{-1}$ dissolved oxygen showed significantly lower $\mathrm{Na}^{+}$effluxes from 24 to $120 \mathrm{~h}$ after transference to $6.0 \mathrm{mg} . \mathrm{L}^{-1}$ dissolved oxygen than those maintained at the same dissolved oxygen levels (Fig. 3A). However, $\mathrm{Cl}^{-}$effluxes of fish accli-
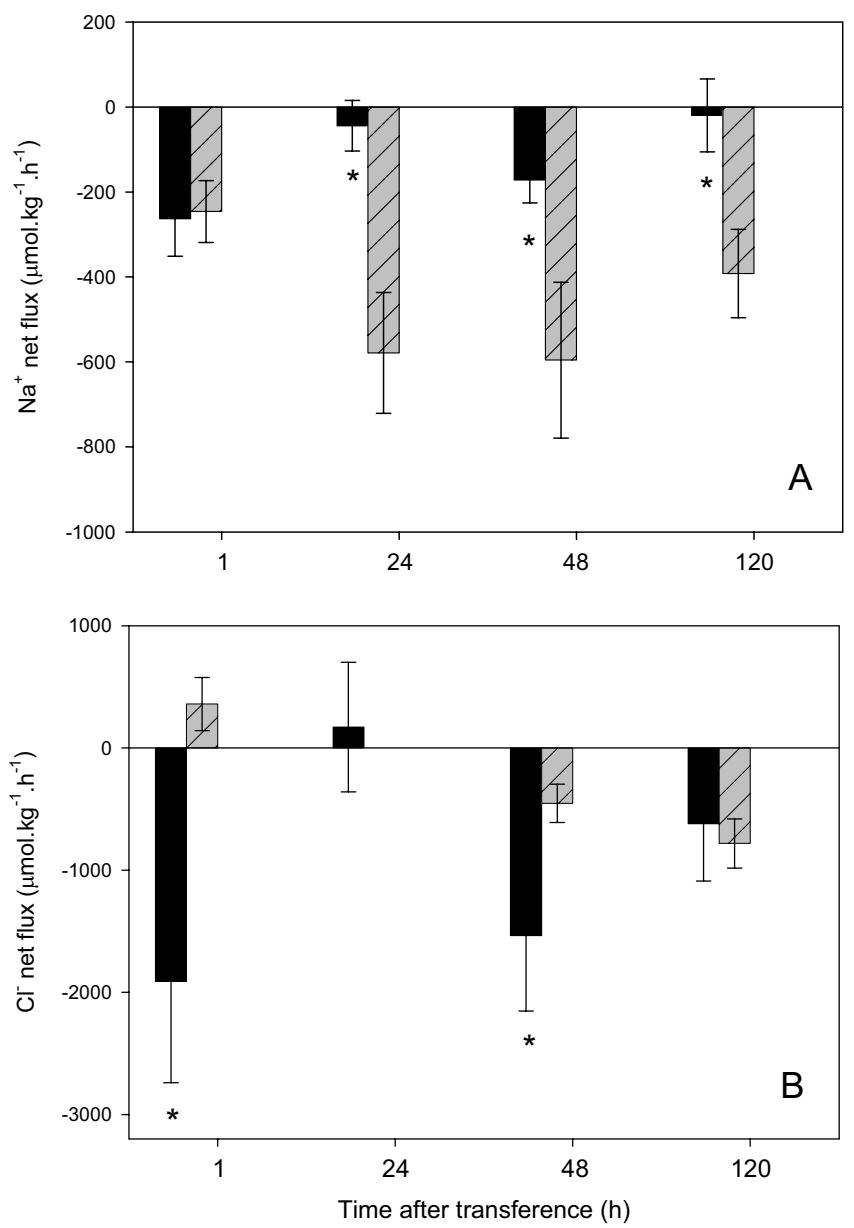

Dissolved oxygen levels (mg. $\left.\mathrm{L}^{-1}\right)$

2.5-6.0 6 6.0-6.0

Fig. 3. $\mathrm{Na}^{+}(\mathrm{A})$ and $\mathrm{Cl}^{-}$(B) net fluxes of silver catfish juveniles acclimated to $2.5(2.5-6.0)$ or $6.0(6.0-6.0) \mathrm{mg} . \mathrm{L}^{-1}$ dissolved oxygen levels for three weeks and transferred to aquaria with $6.0 \mathrm{mg} . \mathrm{L}^{-1}$ dissolved oxygen levels. Data expressed as mean \pm SEM. Positive values indicate net influxes, and negative values net effluxes. Mean value of $\mathrm{Cl}^{-}$flux at $24 \mathrm{~h}$ in juveniles transferred to $6.0 \mathrm{mg} . \mathrm{L}^{-1}$ is too small to be seen in the figure. * significantly different from juveniles transferred to $6.0 \mathrm{mg} . \mathrm{L}^{-1}$ at the same time after transference by one-way ANOVA and Tukey test $(\mathrm{P}<0.05)$. mated to $2.5 \mathrm{mg} . \mathrm{L}^{-1}$ dissolved oxygen were higher 1 and $48 \mathrm{~h}$ after transference to $6.0 \mathrm{mg} . \mathrm{L}^{-1}$ dissolved oxygen than those maintained at the same dissolved oxygen levels (Fig. 3B). Juveniles acclimated to $2.5 \mathrm{mg}$. $\mathrm{L}^{-1}$ dissolved oxygen presented significantly higher $\mathrm{K}^{+}$influx at $48 \mathrm{~h}$ and efflux at 24 and $120 \mathrm{~h}$ after transference to $6.0 \mathrm{mg} . \mathrm{L}^{-1}$ dissolved oxygen than those maintained at the same dissolved oxygen levels (Fig. 4A). Ammonia fluxes were not significantly different in juveniles acclimated at $2.5 \mathrm{mg} . \mathrm{L}^{-1}$ dissolved oxygen and transferred to $6.0 \mathrm{mg} . \mathrm{L}^{-1}$ dissolved oxygen than of those maintained at the same dissolved oxygen levels (Fig. 4B).
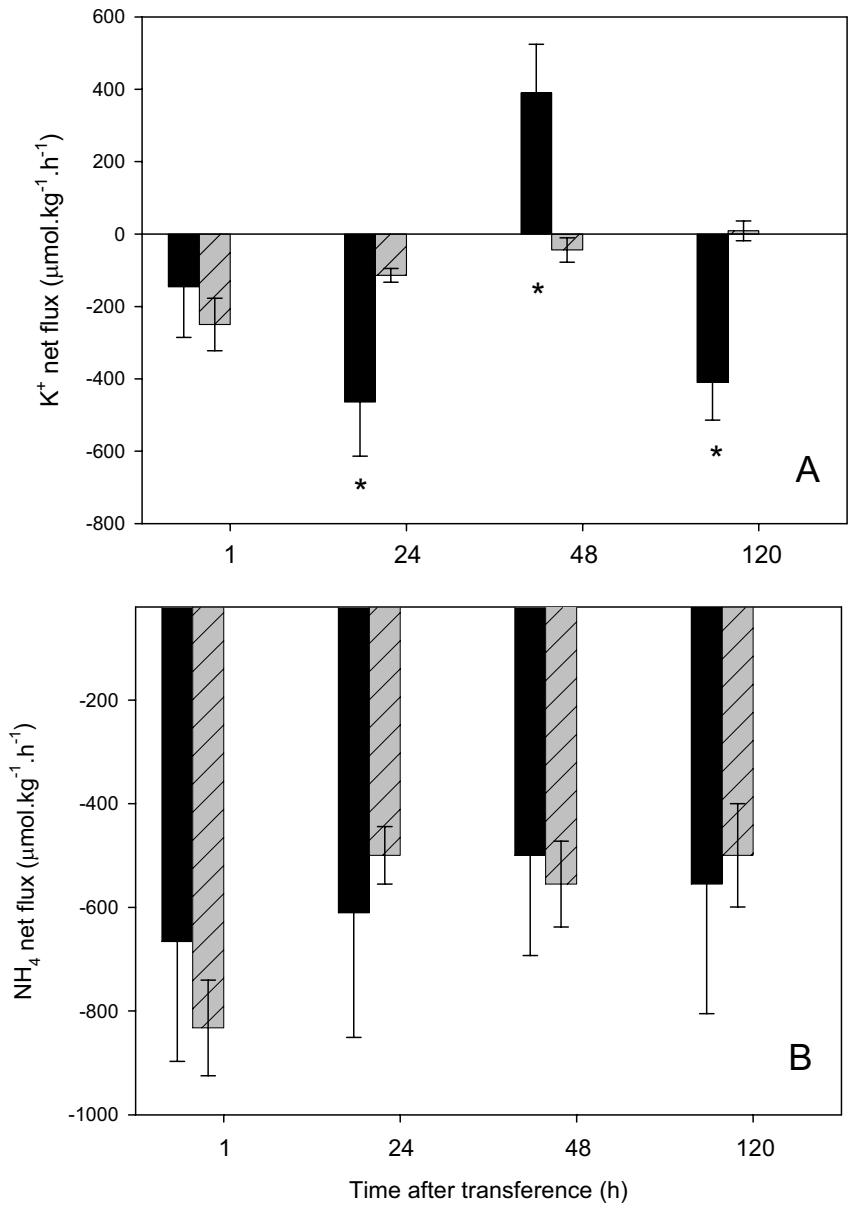

Dissolved oxygen levels $\left(\mathrm{mg} \cdot \mathrm{L}^{-1}\right)$

$2.5-6.0 \nabla \square 6.0-6.0$

Fig. 4. $\mathrm{K}^{+}(\mathrm{A})$ and $\mathrm{NH}_{4}^{+}$(B) net fluxes of silver catfish juveniles acclimated to $2.5(2.5-6.0)$ or $6.0(6.0-6.0) \mathrm{mg} . \mathrm{L}^{-1}$ dissolved oxygen levels for three weeks and transferred to aquaria with $6.0 \mathrm{mg} . \mathrm{L}^{-1}$ dissolved oxygen levels. Data expressed as mean \pm SEM. Positive values indicate net influxes, and negative values net effluxes. * significantly different from juveniles transferred to $6.0 \mathrm{mg}$. $\mathrm{L}^{-1}$ at the same time after transference by one-way ANOVA and Tukey test $\left(\mathrm{NH}_{4}^{+}\right)$or by Kruskall-Wallis Anova and Mann-Whitney test $\left(\mathrm{K}^{+}\right)(\mathrm{P}<0.05)$. 


\section{Discussion}

Dissolved oxygen lethal concentration ( $96 \mathrm{~h}$ ) for silver catfish is $0.52 \mathrm{mg} . \mathrm{L}^{-1}$ (C.I. $0.42-0.61 \mathrm{mg} . \mathrm{L}^{-1}$ ) or $6.7 \%$ oxygen saturation, and mortality did not occur in those exposed to $1.68 \mathrm{mg} . \mathrm{L}^{-1}$ (21.6\% oxygen saturation) or higher dissolved oxygen levels. However, exposure to levels lower than 5.2 mg.L.' ${ }^{-1}(65.6 \%$ oxygen saturation) reduced growth of this species (Braun et al., 2006). In the present study all analyzed dissolved oxygen levels were above lethal limits for this species.

Transference of silver catfish juveniles to new aquaria with the same dissolved oxygen levels apparently did not provoked osmoregulatory disturbance, as ion effluxes were low $1 \mathrm{~h}$ after transference and remained constant up to $120 \mathrm{~h}$. Ammonia effluxes (or excretion) also did not present any significant change throughout the experiment. Net flux values of silver catfish were in the same range of those described for tambaqui (Colossoma macropomum) after overnight recovery in the flux chambers (Gonzalez et al., 1998) and $\mathrm{Na}^{+}$and $\mathrm{Cl}^{-}$effluxes lower than those of Metynnis hypsauchen, a teleost from Rio Negro, Amazon, $2 \mathrm{~h}$ after transference to the flux chambers (Baldisseroto $\&$ Val, 2002). On the other hand, silver catfish juveniles transferred to $2.5 \mathrm{mg} . \mathrm{L}^{-1}$ dissolved oxygen levels in the first hour showed significantly higher $\mathrm{Na}^{+}$and $\mathrm{Cl}^{-}$effluxes than those maintained at $6.0 \mathrm{mg}$. $\mathrm{L}^{-1}$ dissolved oxygen levels. The adaptation of $\mathrm{Na}^{+}$and $\mathrm{Cl}^{-}$fluxes in silver catfish juveniles exposed to this low oxygen level seems to be fast, as $24 \mathrm{~h}$ later these fluxes were similar to fluxes of those maintained at $6.0 \mathrm{mg} . \mathrm{L}^{-1}$ dissolved oxygen levels. However, a different pattern was observed for $\mathrm{K}^{+}$fluxes of juveniles transferred to $2.5 \mathrm{mg} . \mathrm{L}^{-1}$ dissolved oxygen levels: effluxes were higher than of those maintained at $6.0 \mathrm{mg} . \mathrm{L}^{-1}$ dissolved oxygen levels only $48 \mathrm{~h}$ after transference. This indicates that osmoregulatory equilibrium was not complete even $48 \mathrm{~h}$ after the transference. It is possible that the initial disturbance of $\mathrm{Na}^{+}$and $\mathrm{Cl}^{-}$fluxes led to a decrease on plasma levels of these ions, and a consequent decrease on plasma osmolality, as observed by Sakuragui et al. (2003) in Hoplias malabaricus exposed to hypoxia (around $1 \mathrm{mg} . \mathrm{L}^{-1}$ dissolved oxygen levels). This reduction on plasma osmolality could provoke loss of $\mathrm{K}^{+}$from the intracellular medium to the plasma. Higher plasma $\mathrm{K}^{+}$level could induce a higher efflux two days after transference. Apparently some decrease on catabolism might have occurred in silver catfish transferred to $2.5 \mathrm{mg} . \mathrm{L}^{-1}$ dissolved oxygen levels because ammonia effluxes were lower than in those maintained at $6.0 \mathrm{mg}$. $\mathrm{L}^{-}$ dissolved oxygen levels 24 and $120 \mathrm{~h}$ after transference.

Silver catfish transferred to 3.5 and $4.5 \mathrm{mg} . \mathrm{L}^{-1}$ dissolved oxygen levels did not show the same clear pattern on $\mathrm{Na}^{+}, \mathrm{Cl}^{-}$ and ammonia fluxes of those transferred to $2.5 \mathrm{mg} . \mathrm{L}^{-1}$ dissolved oxygen levels. Apparently changes on ventilation rate (and consequently, ion fluxes) only occur when fish are exposed to very low dissolved oxygen levels. For example, in Nile tilapia, Oreochromis niloticus, ventilation rate decreased significantly only when dissolved oxygen levels fell below 1 mg.L. $\mathrm{L}^{-1}$ (Xu et al., 2006). On the other hand, $\mathrm{K}^{+}$fluxes in silver catfish $48 \mathrm{~h}$ after transference to 3.5 and $4.5 \mathrm{mg} . \mathrm{L}^{-1}$ dissolved oxygen levels showed a similar pattern of those transferred to $2.5 \mathrm{mg} . \mathrm{L}^{-1}$ dissolved oxygen levels (except $\mathrm{K}^{+}$efflux $48 \mathrm{~h}$ after transference in fish transferred to $4.5 \mathrm{mg} . \mathrm{L}^{-1}$ dissolved oxygen levels, which were comparatively very high). There is no apparent reason for this discrepancy.

Exposure to hypoxia stimulates chemoreceptors in the gills, producing a reflex bradycardia and usually an increase in arterial blood pressure (Milsom et al., 1999). Hypoxia also causes catecholamine release (Reid et al., 1998, Reid \& Perry, 2003) and consequent adrenergic constriction of the arterio-venous pathway, increasing branchial perfusion pressure. This process promotes lamellar recruitment to increase respiratory surface area and, consequently, gas exchange (Sundin, 1999). Therefore, silver catfish juveniles transferred to $2.5 \mathrm{mg}$. $\mathrm{L}^{-1}$ dissolved oxygen levels would increase their respiratory surface area to improve oxygen uptake, which could explain their higher $\mathrm{Na}^{+}$and $\mathrm{Cl}^{-}$net effluxes by diffusion in the first hour after transference. In addition, as hypoxia inhibited ion transporters in fish erythrocytes and hepatocytes (Nikinmaa, 2002), ion influx by osmoregulatory organs might also be affected, but studies regarding this subject are still missing.

When silver catfish adapted to hypoxia $\left(2.5 \mathrm{mg} . \mathrm{L}^{-1}\right.$ dissolved oxygen level) is transferred from to $6.0 \mathrm{mg} . \mathrm{L}^{-1}$ dissolved oxygen levels a decrease on gill ventilation would reverse the situation, explaining why $24 \mathrm{~h}$ after transference net $\mathrm{Na}^{+}$ effluxes were lower than of those maintained at $6.0 \mathrm{mg} \cdot \mathrm{L}^{-1}$ dissolved oxygen levels. In agreement with this hypothesis, Nile tilapia transferred from hypoxic levels (around $1.0 \mathrm{mg} . \mathrm{L}^{-}$ ${ }^{1}$ dissolved oxygen levels) to normoxic levels showed a decrease on ventilation rate (Xu et al., 2006). There are no studies regarding hypoxia and ion fluxes, but the rate of $\mathrm{Na}^{+}$loss per unit of oxygen consumed is similar in several teleosts species investigated, as rainbow trout, common shiner, lake trout, killifish, smallmouth bass, and banded sunfish. Gill blood flow increases when fish are submitted to exhaustive exercise because they need higher oxygen input. This circulatory change probably distorts and widens gill tight junctions, making them more permeable to ions (Gonzalez \& McDonald, 1992 , 1994). The same could happen in fish exposed to hypoxic levels. However, $\mathrm{Cl}^{-}$effluxes in silver catfish transferred from 2.5 to $6.0 \mathrm{mg} . \mathrm{L}^{-1}$ dissolved oxygen levels were higher 1 and $48 \mathrm{~h}$ after transference than of those maintained at 6.0 mg. $\mathrm{L}^{-1}$ dissolved oxygen levels, which indicates that possibly mechanisms regulating $\mathrm{Cl}^{-}$fluxes present some differences from those regulating $\mathrm{Na}^{+}$fluxes. $\mathrm{K}^{+}$fluxes in silver catfish transferred from 2.5 to $6.0 \mathrm{mg} . \mathrm{L}^{-1}$ dissolved oxygen levels also did not present a clear relationship as $\mathrm{Na}^{+}$fluxes.

The obtained results allow concluding that exposure to $2.5 \mathrm{mg} . \mathrm{L}^{-1}$ dissolved oxygen levels promotes loss of ions and lower ammonia excretion in silver catfish juveniles, but these losses are rapidly stabilized for $\mathrm{Na}^{+}$and $\mathrm{Cl}^{-}$. Exposure to less hypoxic levels also changes ion fluxes and ammonia excretion, but there is no clear relationship between both parameters in this species. Therefore, silver catfish osmoregulation seems to be affected when this species is transferred from normoxic to hypoxic waters and vice-versa. 


\section{Acknowledgements}

The authors thank Conselho Nacional de Pesquisa e Desenvolvimento Científico $(\mathrm{CNPq})$ by providing research grant to B. Baldisserotto and undergraduate scholarship (process 501381/2004-0) to F.L. de Rosso.

\section{Literature Cited}

Baldisserotto, B. 2003. Osmoregulatory adaptations of freshwater teleosts. Pp. 179-201. In: Val, A. L. \& B.G. Kapoor (Eds.) Fish Adaptations. Enfield, Science Publishers, 418p.

Baldisserotto, B. \& A. L. Val. 2002. Ion fluxes of Metynnis hypsauchen, a teleost from the Rio Negro, Amazon, exposed to an increase of temperature. Brazilian Journal of Biology, 62: 749-752.

Braun, N., R. L. Lima, B. Moraes, V. L. Loro \& B. Baldisserotto. 2006. Survival, growth and biochemical parameters of silver catfish, Rhamdia quelen (Quoy \& Gaimard, 1824), juveniles exposed to different oxygen levels. Aquaculture Research, 37: 1524-1531.

Evans, D. H., P. M. Piermarini \& K. P. Choe. 2005. The multifunctional fish gill: dominant site of gas exchange, osmoregulation, acid-base regulation, and excretion of nitrogenous waste. Physiological Revue, 85: 97-177.

Gonzalez, R. J. \& D. G. McDonald. 1992. The relationship between oxygen consumption and ion loss in a freshwater fish. The Journal of Experimental Biology, 163: 317-332.

Gonzalez, R. J. \& D. G. McDonald. 1994. The relationship between oxygen uptake and ion loss in fish from diverse habitats. The Journal of Experimental Biology, 190: 95-108.

Gonzalez, R. J., C. M. Wood, R. W. Wilson, M. J. Patrick, H. L. Bergman, A. Narahara \& A. L. Val. 1998. Effects of water pH and calcium concentration on ion balance in fish of the Rio Negro, Amazon. Physiological Zoology, 7(1): 15-22.
Milsom, W. K., L. Sundin, S. Reid, A. Kalinin, \& F. T. Rantin. 1999. Chemoreceptor control of cardiovascular reflexes. Pp. 363-374. In: Val, A. L. \& V. M. F. Almeida-Val (Eds.). Biology of Tropical Fishes. Manaus, INPA, 460p.

NIkinmaa, M. 2002. Oxygen-dependent cellular functions - why fishes and their aquatic environment are a prime choice of study. Comparative Biochemistry and Physiology Part A, 133: 1-16.

Rantin, F. T. \& M. A. Marins. 1984. Como os teleósteos respondem à hypoxia ambiental - Uma revisão. Anais do Simpósio Brasileiro de Aqüicultura III. São Carlos, SP. p.673-692.

Reid, S. G., N. J. Bernier \& S. F. Perry. 1998. The adrenergic stress response in fish: control of catecholamine storage and release. Comparative Biochemistry and Physiology, 120C: 1-27.

Reid, S. G. \& S. F. Perry. 2003. Peripheral O-2 chemoreceptors mediate humoral catecholamine secretion from fish chromaffin cells. American Journal of Physiology-Regulatory Integrative and Comparative Physiology 284: R990-R999.

Sakuragui, M. M., J. R. Sanches \& M. N. Fernandes. 2003. Gill chloride cell proliferation and respiratory responses to hypoxia of the neotropical erythrinid fish Hoplias malabaricus. Journal of Comparative Physiology B, 173: 309-317.

Sundin, L. 1999. Hypoxia and blood flow control in fish gills. Pp.353362. In: Val, A. L. \& V. M. F. Almeida-Val (Eds.). Biology of Tropical Fishes. Manaus, INPA, 460p.

Verdouw, H., C. J. A. Vanechteld \& E. M. J. Deckkers. 1978. Ammonia determinations based on indophenol formation with sodium salicylate. Water Research, 12: 399-402.

Xu, J., Y. Liu, S. Cui \& X. Miao. 2006. Behavioral responses of tilapia (Oreochromis niloticus) to acute fluctuations in dissolved oxygen levels as monitored by computer vision. Aquacultural Engineering, 35: 207-217.

Zall, D. M., M. D. Fisher \& Q. M. Garder. 1956. Photometric determination of chlorides in water. Analytical Chemistry, 28: 1665-1678.

Submitted June 2006 Accepted November 2006 